\title{
A strategy to rehabilitate fishes of the Murray-Darling Basin, south-eastern Australia
}

\author{
John D. Koehn ${ }^{1, *}$, Mark Lintermans ${ }^{2}$ \\ ${ }^{1}$ Arthur Rylah Institute for Environmental Research, Department of Sustainability and Environment, \\ 123 Brown St, Heidelberg, Victoria 3084, Australia \\ ${ }^{2}$ Institute for Applied Ecology, University of Canberra, Canberra, ACT 2601, Australia
}

\begin{abstract}
The Native Fish Strategy (NFS) for the Murray-Darling Basin, south-eastern Australia, provides a whole-of-fish-community approach and coordinated direction for the rehabilitation of its severely degraded native fish populations. Together with actions outlined in recovery plans for threatened species, the NFS addresses priority threats identified for native fishes with the aim to rehabilitate native fish populations to $60 \%$ (current populations are estimated to be at about $10 \%$ ) of the levels that existed prior to European settlement. The NFS has a 50 yr time frame and coordinates actions across 6 different management jurisdictions. A key component of the NFS is the engagement of communities and stakeholders, with this being undertaken, in particular, by the use of dedicated coordinators and the development of 'demonstration reaches' where rehabilitation can be undertaken using multiple actions, with community involvement. The NFS is supported by targeted research projects and monitoring within an adaptive management framework. The NFS provides an effective partnership model where central coordination, coupled with focused jurisdictional actions, can deliver benefits to all governments. It synthesises and disseminates knowledge, integrates research and management and catalyses actions for priority problems. The need, objectives, evolution and development, achievements, strengths and weaknesses of the NFS are presented. The NFS approach would be suitable for many large river basins throughout the world.
\end{abstract}

KEY WORDS: Australia $\cdot$ Rehabilitation - Fish populations $\cdot$ Native Fish Strategy $\cdot$ Threatened species $\cdot$ Native fish

Resale or republication not permitted without written consent of the publisher

\section{INTRODUCTION}

Freshwater habitats are amongst the most threatened in the world (Sala et al. 2000, Malmqvist \& Rundle 2002, Dudgeon et al. 2006), with their largely linear and unidirectional flow characteristics making them highly susceptible to anthropogenic impacts. Lakes and rivers comprise $<0.01 \%$ of the Earth's water, yet freshwater fish comprise around $40 \%$ of the world's fish fauna (Dudgeon et al. 2006, Nelson 2006, Jelks et al. 2008), with 30 to $60 \%$ of species considered threatened in many regional assessments
(Smith \& Darwall 2006, Jelks et al. 2008, Garcia et al. 2010). Rehabilitation of freshwater habitats to recover aquatic fauna is a rapidly growing management area (Cowx \& Welcomme 1998, Bernhardt et al. 2005), with the recovery of fishes being a common objective (Roni et al. 2005).

Australia has relatively few freshwater fish species (approximately 260; Allen et al. 2002, Pusey et al. 2004) for its land mass $\left(7692024 \mathrm{~km}^{2}\right)$, largely the result of a generally arid climate and historical isolation. Australian rivers have very low runoff (on average only $12 \%$ of rainfall is collected in rivers; 
NLWRA 2001) and highly variable flows compared to the rest of the world (Puckridge et al. 1998, Arthington \& Pusey 2003). This climatic and hydrological variability has stimulated high investment in water storage and irrigation infrastructure, particularly in south-eastern Australia. The Murray-Darling Basin (MDB) (Fig. 1) is the food bowl of Australia, covering $>1$ million $\mathrm{km}^{2}$, contributing $39 \%$ of the nation's agricultural production and accounting for $50 \%$ of the nation's irrigated agricultural water use (2007 to 2008; Murray-Darling Basin Authority 2010). The concentration of agricultural development in the MDB has resulted in significant ecological pressure on aquatic systems, with high levels of flow regulation, water abstraction, and floodplain and riparian modification (Murray-Darling Basin Commission 2004). The MDB also has a depauperate native fish fauna of only 44 naturally occurring species (Lintermans 2007), many of which are of conservation concern (Table 1) and which are being impacted by a range of threats (Murray-Darling Basin Commission 2004) (Table 2). The fish fauna of the MDB is essentially riverine, with lacustrine habitats being mainly small in size and predominantly occurring on the floodplain, still dependent on over-bank river flows (Lintermans 2007). Previous conservation management has focussed on individual species; however, it is increasingly recognised that more holistic approaches may secure better conservation outcomes (Likens et al. 2009).

Many of the MDB native fishes are highly recognised and valued by the community, especially in

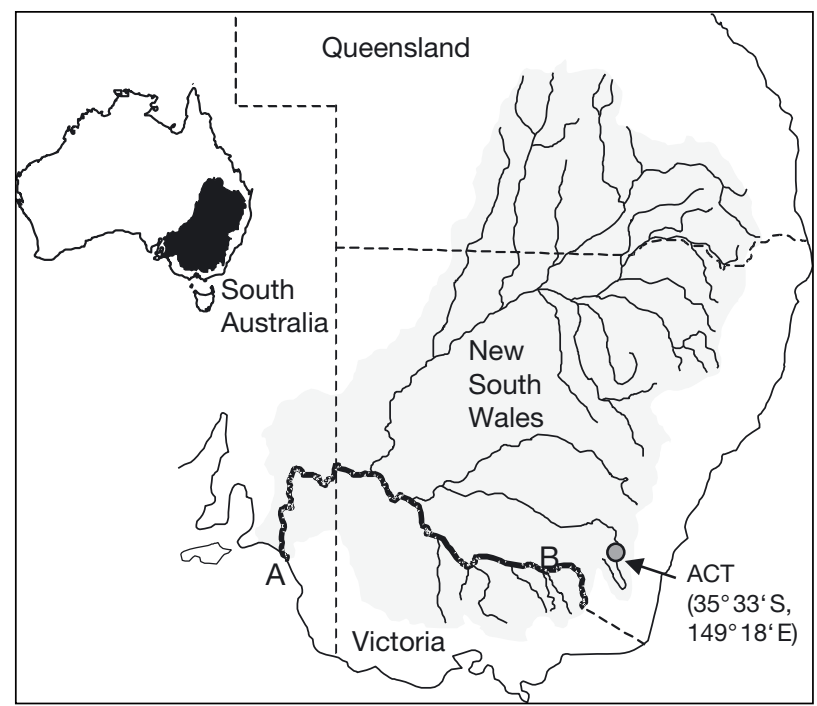

Fig. 1. Murray-Darling Basin, south-eastern Australia. Dark line: Murray River; A: Murray River mouth; B: Hume Dam; ACT: Australian Capital Territory regional areas. Native fish have important ecological, social, cultural and economic values and provide a key link between people and their river systems. They have particular significance and importance to Australian indigenous cultures, for example, 'in aboriginal mythology the Murray cod was responsible for the creation of the Murray River and its fish' (Rowland 2005, p. 40). Native fishes also provide considerable opportunities for recreational angling and contribute to rural economies through related tourism (Henry \& Lyle 2003).

The MDB encompasses 4 states and a territory (hereafter collectively termed 'states') and, together with the commonwealth (national government), is subject to 6 legislative jurisdictions and their governmental departments and agencies with many and varied disparate responsibilities. This complexity presents considerable challenges to effective management of natural resources. Whilst water use and management has been coordinated across jurisdictions through the Murray-Darling Basin Authority (MDBA, previously Murray-Darling Basin Commission), native fish management has traditionally been single-issue dominated and undertaken on an individual state-bystate basis, with community involvement (especially outside organised recreational angler groups) being limited. Fish management has generally been focussed on threatened or angling species (sometimes managed by different departments), with many other species being neglected. Threatened species management largely revolves around individual species recovery plans, and, while these have made significant gains for these species (e.g. barred galaxias; Raadik et al. 2010), there are opportunities for wider integration. For example, the commonwealth and states have different conservation listing processes (see Table 1), and some jurisdictions also have separate fisheries plans. Almost invariably there is a disconnection between the management of fish and management of their habitats, especially the management of water. The high degree of river regulation and utilisation of water for irrigation means that, as well as competition between environmental and agricultural needs (Kingsford 2000, Arthington \& Pusey 2003), competition for environmental water allocations also exist between different ecological assets (e.g. vegetation, waterbirds, fish).

The present paper outlines the innovative approach taken by the 'Native Fish Strategy for the Murray-Darling Basin 2003-2013' (NFS) (MurrayDarling Basin Commission 2004) to address the impacts of key threatening processes and to rehabilitate populations of both threatened and non-threat- 
Table 1. Threatened fish species in Murray-Darling Basin (MDB), according to state, territory and national listings. Note: species classified as rare have been excluded; there are no MDB fish species formally listed in Queensland. ACT: Australian Capital Territory; NSW: New South Wales; VIC: Victoria; SA: South Australia, Action Plan for SA Freshwater Fishes (Hammer et al. 2009); EX: extinct in the wild; CE: critically endangered; EN: endangered; VU: vulnerable; EN POP: endangered population; DD: data deficient; L: listed under the Victorian Flora \& Fauna Guarantee Act 1988; (...): conservation status under DSE (2007) advisory listing in Victoria; EPBC: national status under the Environment Protection and Biodiversity Conservation Act 1999; ASFB: national status listed by the Australian Society for Fish Biology (Lintermans 2010)

\begin{tabular}{|c|c|c|c|c|c|c|c|}
\hline Scientific name & Common name & $\mathrm{ACT}$ & NSW & VIC & $\mathrm{SA}$ & ЕРBC & ASFB \\
\hline Galaxias olidus & Mountain galaxias & & & & VU & & \\
\hline Galaxias fuscus & Barred galaxias & & & $\mathrm{L}\{\mathrm{CE}\}$ & & EN & $\mathrm{CE}$ \\
\hline Galaxias truttaceus ${ }^{\mathrm{a}}$ & Spotted galaxias & & & & EN & & \\
\hline Galaxias rostratus & Flat-headed galaxias & & $\mathrm{CE}$ & $\{\mathrm{VU}\}$ & EX & & VU \\
\hline Gadopsis bispinosus & Two-spined blackfish & VU & & & & & \\
\hline Gadopsis marmoratus & Northern river blackfish & & EN POP & & EN & & \\
\hline Macquaria colonorum & Estuary perch & & & & EN & & \\
\hline Macquaria australasica & Macquarie perch & EN & EN & $\mathrm{L}\{\mathrm{EN}\}$ & $\mathrm{EX}$ & EN & $\mathrm{EN}$ \\
\hline Macquaria ambigua & Golden perch & & & \{VU\} & & & \\
\hline Maccullochella peelii & Murray cod & & & $\mathrm{L}\{\mathrm{EN}\}$ & EN & VU & VU \\
\hline $\begin{array}{l}\text { Maccullochella } \\
\text { macquariensis }\end{array}$ & Trout cod & EN & EN & $\mathrm{L}\{\mathrm{CE}\}$ & $\mathrm{EX}$ & EN & $\mathrm{CE}$ \\
\hline Tandanus tandanus & Freshwater catfish & & EN POP & $\mathrm{L}\{\mathrm{EN}\}$ & EN & & \\
\hline Bidyanus bidyanus & Silver perch & EN & VU & $\mathrm{L}\{\mathrm{CE}\}$ & EN & & VU \\
\hline Mordacia mordax & Short-headed lamprey & & & & EN & & \\
\hline Geotria australis & Pouched lamprey & & & & EN & & \\
\hline Pseudaphritis urvillii & Congolli & & & & VU & & \\
\hline Mogurnda adspersa & Southern purple-spotted gudgeon & & EN & $\mathrm{L}\{\mathrm{EX}\}$ & $\mathrm{CE}$ & & \\
\hline Ambassis agassizii & Olive perchlet & & EN POP & $\mathrm{L}\{\mathrm{EX}\}$ & $\mathrm{CE}$ & & \\
\hline Nannoperca australis & Southern pygmy perch & & EN & & EN & & \\
\hline Nannoperca obscura & Yarra pygmy perch & & & $\mathrm{L}$ & $\mathrm{CE}$ & VU & VU \\
\hline $\begin{array}{l}\text { Craterocephalus } \\
\text { fluviatilis }\end{array}$ & Murray hardyhead & & $\mathrm{CE}$ & $\mathrm{L}\{\mathrm{CE}\}$ & $\mathrm{CE}$ & VU & $\mathrm{EN}$ \\
\hline $\begin{array}{l}\text { Craterocephalus } \\
\text { stercusmuscarum fulvus }\end{array}$ & Unspecked hardyhead & & & $\mathrm{L}\{\mathrm{DD}\}$ & & & \\
\hline $\begin{array}{l}\text { Craterocephalus } \\
\text { amniculus }\end{array}$ & Darling River hardyhead & & & & & & VU \\
\hline Melanotaenia fluviatilis & Murray-Darling rainbowfish & & & $\mathrm{L}\{\mathrm{DD}\}$ & & & \\
\hline
\end{tabular}

ened native fishes. It discusses the development of this strategy, evaluates its strengths and weaknesses, discusses threats to it and future opportunities, providing a case study that may be applicable to other parts of the world.

\section{THE NEED FOR ACTION}

The health of native fish populations and communities in the MDB is one indicator of the overall health of the basin and its rivers (Harris 1995). The current poor status of native fish populations in the MDB is alarming, with several indicators demonstrating the urgency of the current situation:

- Reductions or localised extinction of some native fish species (see Cadwallader 1977, Cadwallader \& Gooley 1984, Lintermans 2007)
- A wide range of threats to species (Table 2)

- Nine of the 44 naturally occurring native fish species in the basin nationally 'threatened' (Lintermans 2010) and an additional 14 species listed by states (Table 1; Lintermans 2007).

- Rapid declines in key recreational and commercial 'flagship' species such as silver perch Bidyanus bidyanus, freshwater catfish Tandanus tandanus and Murray cod Maccullochella peelii across the basin (Cadwallader \& Gooley 1984, Reid et al. 1997, Clunie \& Koehn 2001a,b).

- The closure of commercial fisheries for native species.

- The presence of 12 alien species of fish that now comprise a quarter of the total fish species (including carp Cyprinus carpio that now make up an estimated 80 to $90 \%$ of fish biomass at many sites; Harris \& Gehrke 1997, Lintermans 2007). 
Table 2. Key general threats to fish in the Murray-Darling Basin (modified from Cadwallader 1978, Koehn \& O'Connor 1990, Murray-Darling Basin Commission 2004)

\begin{tabular}{|c|c|c|}
\hline Threat & Description & Sources \\
\hline Flow regulation & $\begin{array}{l}\text { Loss of flow, flow variation and seasonality, loss of low to } \\
\text { medium floods, permanent flooding, extended periods } \\
\text { of no and low flow }\end{array}$ & $\begin{array}{l}\text { Close (1990), Kingsford (2000), } \\
\text { Arthington \& Pusey (2003) }\end{array}$ \\
\hline $\begin{array}{l}\text { Habitat } \\
\text { degradation }\end{array}$ & $\begin{array}{l}\text { Damage to riparian zones, removal of in-stream habitats, } \\
\text { sedimentation }\end{array}$ & Lyon \& O'Connor (2008) \\
\hline $\begin{array}{l}\text { Lowered water } \\
\text { quality }\end{array}$ & $\begin{array}{l}\text { Increased nutrients, turbidity, sedimentation, salinity, } \\
\text { artificial changes in water temperature, pesticides } \\
\text { and other contaminants }\end{array}$ & $\begin{array}{l}\text { Phillips (2001), Lyon \& O'Connor } \\
\text { (2008), Sherman et al. (2007) }\end{array}$ \\
\hline Barriers & $\begin{array}{l}\text { Impediments to fish passage, e.g. dams, weirs, levees, } \\
\text { culverts, and non-physical barriers such as } \\
\text { increased velocities, reduced habitats, water quality } \\
\text { and thermal pollution (changes in water temperature); } \\
\text { loss of population connectivity }\end{array}$ & $\begin{array}{l}\text { Jones \& Stuart }(2004,2008), \text { Barrett \& } \\
\text { Mallen-Cooper (2006), Barrett (2008), } \\
\text { Stuart et al. (2008) }\end{array}$ \\
\hline Alien species & Competition with and/or predation by alien species & Koehn (2004b), Ansell \& Jackson (2007) \\
\hline Exploitation & $\begin{array}{l}\text { Recreational and commercial }{ }^{\mathrm{a}} \text { fishing pressure on } \\
\text { depleted stocks, illegal fishing }\end{array}$ & Nicol et al. (2005), Rowland (2005) \\
\hline Diseases & $\begin{array}{l}\text { Outbreak and spread of epizootic haematopoietic } \\
\text { necrosis virus and other viruses, diseases and parasites }\end{array}$ & Whittington et al. (2010) \\
\hline $\begin{array}{l}\text { Translocation and } \\
\text { stocking }\end{array}$ & $\begin{array}{l}\text { Loss of genetic integrity and fitness caused by } \\
\text { inappropriate translocation and stocking of native species }\end{array}$ & Phillips (2003), Nock et al. (2011) \\
\hline
\end{tabular}

- The presence of several translocated native fish species not endemic to the basin's rivers (e.g. broadfinned galaxias Galaxias brevipinnis; Waters et al. 2002).

- Observed declines in recreational angling success. In addition to the listing of threatened species, several fish communities of the MDB have also been listed as threatened under both state (Victorian and New South Wales) and commonwealth legislation. The only broad-scale pre-NFS assessment of fish 'health' documented NSW rivers in the basin as being degraded, with many expected fish species not captured, high abundance of alien species, and significant impacts of river regulation (Harris \& Gehrke 1997). Recognising that action should not be delayed while waiting for perfect knowledge, the need for a coordinated strategy to rehabilitate fish populations was obvious, and out of this perception the concept of the NFS was born in 1999.

The NFS is an ecosystem-based approach that uses on-ground management not only to improve the status of native fish in the MDB but also to increase our ecosystem understanding. This strategy has fish as its focus, rather than being an added component to other strategies (e.g. wetland protection salinity management). It employs a whole-of-fish-community approach, in contrast to the single-species focus of many fish conservation programs and recovery plans. The NFS embodies a commitment between all jurisdictions to rehabilitate native fish populations through addressing existing threats, and reflects agreement that urgent coordinated actions are needed across state boundaries. There is a need to build upon the knowledge gained from past research and management, and to create new knowledge to provide a scientific basis for management. Emphasis is placed on rehabilitation rather than maintaining the status quo which would inevitably result in continuing declines and loss of species (Murray-Darling Basin Commission 2004). As declines have taken place over many years, so must rehabilitation be undertaken over a similar timeframe $-50 \mathrm{yr}$ or more, while recognising the potential for immediate benefits associated with some actions (e.g. provision of fish passage). The level of rehabilitation required to reverse declines varies with species, communities and areas, and needs to be assessed over the medium and longer terms.

\section{EVOLUTION AND DEVELOPMENT OF THE NFS}

The benefits of a basin-wide approach to native fish management had been recognised for some 
time. A precursor to the NFS addressed some issues for the Murray River (the state border between New South Wales and Victoria; see Fig. 1) (Lawrence 1991) and also established a multi-state oversight group of fisheries scientists. Expanding this approach to all rivers in the basin would result in the NFS applying to all native fish across the whole MDB. Importantly, the focus of the NFS is on 'fish', not 'fisheries', although recreational angling is recognised as a key component (Henry \& Lyle 2003). The development of the NFS needed to be undertaken carefully with awareness of existing management structures, in order to enhance existing programs and ensure the long-term support of state management agencies. It was fortunate that the driving force behind the NFS should be an independent body that already comprised state representation (the Murray-Darling Basin Commission, MDBC), and included a fish working group that discussed fish-related issues.

As the prime responsibility for managing rivers and fish populations resides with state governments, inter-state cooperation and coordination of actions and policies was essential, and most interventions will require some state funding. However, the commonwealth, through its funding programs, may supplement state funds for these actions, particularly for issues/problems of national importance (e.g. nationally threatened species) or species/actions on com- monwealth land. Where interventions are required on private land, such as riparian areas, states may use a number of mechanisms (e.g. catchment management bodies) to encourage beneficial actions. These mechanisms range from financial incentives through to regulation. The process for development of the NFS is outlined in Table 3 and includes a strong commitment to engage the community. Engaging both the community and jurisdictional agencies, then incorporating their concerns and comments was a time consuming process, resulting in Stages 1 to 14 (project conception to NFS launch) taking 5 yr.

Early in the development of the NFS a panel of experts was established to provide several independent assessments (Step 3; Table 3). The first of these was to assess the overall status of fish populations. The panel estimated that native fish populations within the MDB were at about $10 \%$ of their pre-European settlement (mid- to late 19th century for the MDB) levels and without any intervention were likely to fall to $5 \%$ over the next 40 to 50 yr (MurrayDarling Basin Commission 2004). Whilst a difficult estimate to quantify (requiring a desktop assessment of all species, their entire range within the MDB, often with limited base-line data, collected with a variety of methods), this figure provided a clear benchmark that was readily understandable by non-

Table 3. Steps in the development of the Native Fish Strategy (NFS). MDBA and MDBC: Murray-Darling Basin Authority and Commission, respectively

\begin{tabular}{lll|}
\hline Step & Year & Steps in the development \\
\hline 1 & 1999 & NFS conception, project development \\
2 & 2000 & Development of outline of Draft NFS, initial stakeholder public meetings \\
3 & 2001 & Establishment of an expert panel (to assess state of fish populations, priority actions, importance of actions) \\
4 & 2001 & NFS drafted, iterations between authors and MDBA and state agency representatives \\
5 & 2001 & Peer review by expert panel and MDBC \\
6 & 2001 & Meetings between MDBC and state agency heads \\
7 & 2002 & Draft NFS released for public comment (6 mo) \\
8 & 2001 & Establishment of first taskforces - including the community stakeholder taskforce \\
9 & 2002 & Stakeholder public meetings (record public comments) \\
10 & 2002 & Collation of public comments and revision of draft NFS \\
11 & 2002 & Engagement of a science journalist to ensure a publicly accessible document \\
12 & 2003 & Agreements with all states and their agencies - signed by 13 different ministers \\
13 & 2003 & Establishment of the NFS advisory panel \\
14 & 2004 & Print, launch and release of NFS 2003-2013 \\
15 & 2004 & Established NFS coordinators and demonstration reaches \\
16 & 2005 & Repeat of stakeholder public meetings \\
17 & 2005 & Establishment of annual implementation reports \\
18 & 2005 & Development of a communication strategy \\
19 & 2006 & Establishment of annual MDB fish forums to disseminate new knowledge and information \\
20 & 2009 & Five year review of NFS \\
21 & 2009 & Workshop to develop and prioritise future directions for the NFS \\
22 & 2011 & NFS 2011-2021 action plan released \\
\hline
\end{tabular}


scientists. To exemplify its importance, prior to this assessment, several influential stakeholders suggested that there was very little wrong with fish populations and that they were possibly around $90 \%$ of historical levels. This expert assessment quickly highlighted and largely dispelled this myth, and, while it did create some controversy and much discussion, no credible alternative figure has yet been offered.

The vision for the NFS is for the MDB to sustain viable fish populations and communities throughout its rivers. The overall goal is to rehabilitate native fish communities in the MDB back to $60 \%$ or better of their estimated pre-European settlement levels after $50 \mathrm{yr}$ of implementation. The NFS seeks to achieve its vision and goal through 13 targeted objectives (Fig. 2) that address the causes of decline for native fish species (i.e. threats to them). Many of these threats relate to ecological processes and the focus is on long-term rehabilitation. In order to simplify this approach, these objectives were combined to form 6 key driving actions (Fig. 2), each of which incorporate management, research and investigation and community engagement components.

The initial panel of experts was asked to assess the relative merit of each of the required interventions should they be implemented. They believed that, if only 1 strategic intervention were to occur, such as allocation of environmental flows, this may help to recover native fish populations to about $25 \%$ of their estimated pre-European settlement levels. It was agreed, however, that actions must be undertaken in an integrated way if they are to be effective and have

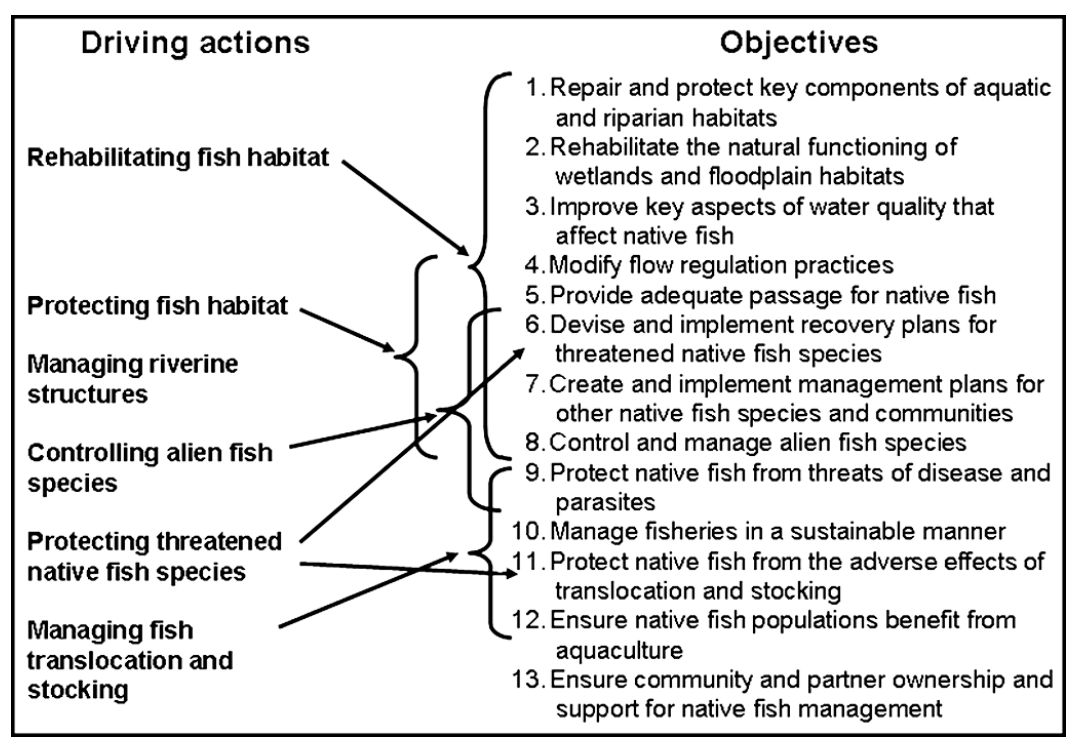

Fig. 2. Objectives and driving actions for the Native Fish Strategy a realistic possibility of achieving the $60 \%$ pre-European target (see Murray-Darling Basin Commission 2004).

Community involvement and support for the NFS is important. The 6 mo public consultation period on a draft NFS in 2002 (Murray-Darling Basin Commission 2002), combined with a series of public forums in regional centres, demonstrates the importance that has been placed on incorporation of the public perspective. The early formation of a Community Stakeholder Taskforce provided a significant new component to the management of fish in Australia. It helped provide community ownership of actions and priorities and a link to the science underpinning the strategy. This is also supported by NFS coordinators in each state who link research and projects to management. They organise an annual 'Native Fish Awareness Week' that highlights the importance of native fishes and provides annual NFS reports. The coordinators act as knowledge brokers, engage with a variety of stakeholders, work directly on projects, embed fish into wider catchment management programs, and form links within and between the jurisdictions. Engagement of the community and stakeholders also occurs through a formal communication strategy.

Implementation of the NFS is best underpinned by science, within a framework of adaptive management. As there are considerable gaps in our knowledge of both species ecology and the impacts of threats, there is a need for the generation of new knowledge. The governance arrangements of the management of the NFS are based around representation from the individual jurisdictions through an NFS Advisory Panel (Fig. 3). The NFS Advisory Panel consists of a policy and science representative from each state together with representatives from the MDBA and major commonwealth agencies. It is supported by taskforces ( 6 at present: Community Stakeholder Group, Alien Fish, Fish Passage, Demonstration Reach, Habitat Management Areas, Murray Cod), that may be created (or disbanded) as required (Fig. 3).

There is world-wide recognition of the need for long-term monitoring and datasets (Lindenmayer \& Likens 2009, 2010). In the MDB, the longterm and broad-scale response of fish communities to management actions (NFS and other programs) is monitored and evaluated to measure suc- 


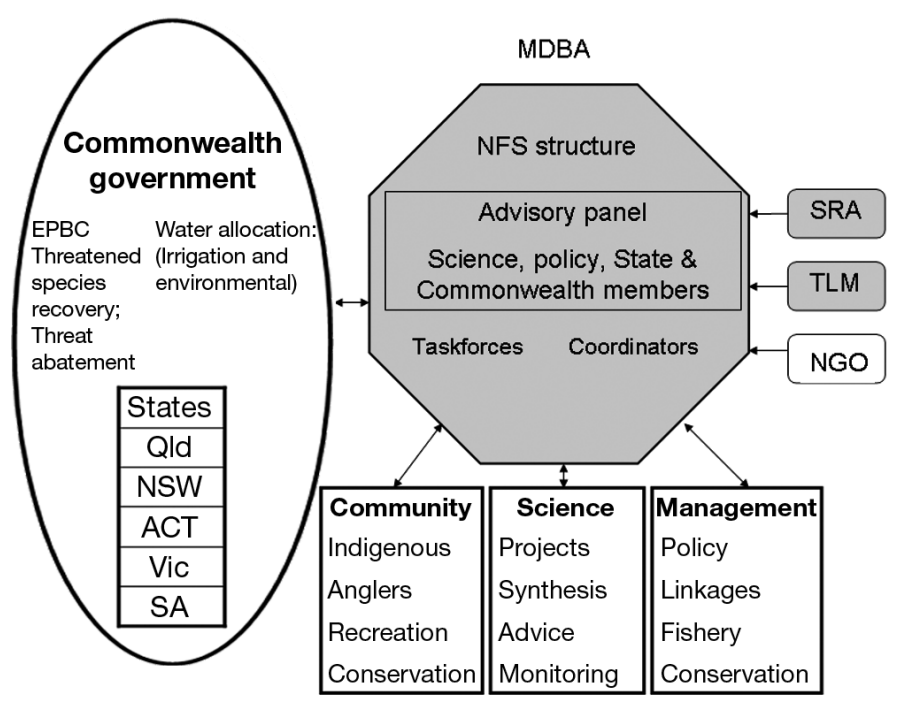

Fig. 3. Management structure of the Native Fish Strategy (NFS). Shading indicates Murray-Darling Basin Authority (MDBA) components. EPBC: Environmental Protection and Biodiversity Conservation Act; NGO: non-government organisations; SRA: Sustainable Rivers Audit; TLM: The Living Murray Environmental Watering program

cess by the Sustainable Rivers Audit (SRA), a longterm 'Condition' monitoring program that measures fish community health across all 23 river valleys in the MDB (Davies et al. 2008, 2010). Results effectively benchmark fish community condition in each valley prior to NFS actions having effect, with no valley rated as 'good' (the top ranking), 3 valleys as 'moderate' and 20 valleys as 'poor', 'very poor', or 'extremely poor' (Davies et al. 2010). This reinforced the '10\% population' status assessment, and, whilst a prolonged and extreme drought will have almost certainly contributed to this poor result, it leaves little doubt as to the necessity for the NFS and the massive task it faces. The NFS is also supported by intervention monitoring to evaluate particular management actions.

In order to provide new knowledge to support management actions in an adaptive context, the NFS has also initiated and funded considerable relevant scientific research and comprehensive rehabilitation of river reaches (see section below and Table 4).

\section{KEY ACHIEVEMENTS OF THE NFS}

Key achievements of the NFS relating to each driving action are documented in Table 4 . The outputs demonstrate the efforts undertaken to actively obtain and promote new knowledge for use in management (often in 'grey' literature), as well as in peer-reviewed publications. It also provides examples of the types of investigation and supporting knowledge that may be needed for strategies such as the NFS. A key achievement of the NFS, and its continued implementation, has been its success in raising awareness and garnering support for the management of native fish across the MDB (Cottingham et al. 2009). This has been facilitated through a range of general and specifically focussed activities targeting clearly identified audiences, including regional natural resource and catchment management practitioners, the general community and recreational anglers. The provision of a range of communication forums and products (see Table 4) has provided a variety of access points and levels of information on the threats and management needs of native fish. This has assisted knowledge sharing and improved communication and partnerships between ecologists and managers, between the jurisdictional agencies and between the NFS and the community.

The need for scientific knowledge and its synthesis was recognised as a key component of the NFS, as traditionally, the take-up of such knowledge in natural resource management has been recognised to be low (Koehn 2004a). The synthesis of existing knowledge provides an important step in the uptake of such knowledge (Murray et al. 2011). To aid this, a series of workshops based on priority issues, knowledge gaps, or objectives were conducted and used to collate the latest science, inform the relevant agencies, identify priority issues and provide recommendations for management and future research. These workshops covered issues ranging from stocking and translocation of fish species and aquatic habitat rehabilitation, to the management of particular species such as the Murray cod (Table 4). The outputs from these workshops have directed and catalysed research and management activities both within and outside the MDB (e.g. King \& O'Connor 2007, Sherman et al. 2007, Drew 2008, Baumgartner et al. 2009, Todd \& Koehn 2009). The NFS has also developed a significant research portfolio dedicated to MDB fish, based around a collaborative approach to identifying issues, research needs and priorities followed by competitive tendering for research provision. This approach has provided a focussed and highly relevant suite of research projects that have direct management or policy implications (Table 4 and references therein), with significant and often rapid uptake by management agencies. 
Table 4. Key achievements of the Native Fish Strategy (NFS) to date

\begin{tabular}{|c|c|c|}
\hline $\begin{array}{l}\text { NFS driving action } \\
\text { addressed }\end{array}$ & NFS achievements & Outputs \\
\hline Rehabilitating fish & $\begin{array}{l}\text { Demonstration reaches, monitoring guidelines, } \\
\text { resnagging, impact of regulators, lateral } \\
\text { movement, environmental watering, wetlands, } \\
\text { coldwater pollution workshop, thermal shock } \\
\text { scoping study, salinity review }\end{array}$ & $\begin{array}{l}\text { Phillips (2001, 2006), Clunie et al. (2002), } \\
\text { Nicol et al. (2002, 2004), Barrett \& Ansell } \\
\text { (2003, 2005), Ryan et al. (2003), Barrett (2004), } \\
\text { Jones \& Stuart (2004, 2008), Koehn et al. (2004a), } \\
\text { Lintermans et al. (2005), Jones (2006), King et } \\
\text { al. (2007, 2009, 2010), Sherman et al. (2007), } \\
\text { Boys et al. (2008, 2009), Tonkin et al. (2008) }\end{array}$ \\
\hline $\begin{array}{l}\text { Protecting fish } \\
\text { habitat }\end{array}$ & $\begin{array}{l}\text { Fish habitat review, fish management zones, } \\
\text { mesoscale movement study, drought refugia and } \\
\text { resilience projects }\end{array}$ & $\begin{array}{l}\text { SKM (2003), Phillips \& Butcher (2005), } \\
\text { Phillips (2008), Hutchison et al. (2008) }\end{array}$ \\
\hline $\begin{array}{l}\text { Managing riverine } \\
\text { structures }\end{array}$ & $\begin{array}{l}\text { Sea to Hume fishway program, downstream } \\
\text { movement workshop and studies, fish counting } \\
\text { technology, fish damage and mortalities due to } \\
\text { irrigation infrastructure }\end{array}$ & $\begin{array}{l}\text { Koehn (2001), Gilligan \& Schiller (2003), Koehn et } \\
\text { al. (2004b), Lintermans \& Phillips (2004), } \\
\text { O'Connor et al. (2005, 2006), Baumgartner et al. } \\
\text { (2006a,b), Barrett \& Mallen Cooper (2006), } \\
\text { King \& O'Connor (2007), Barrett (2008), Berghuis } \\
\text { (2008), Stuart et al. (2008, 2009), Baumgartner } \\
\text { et al. (2009, 2010) }\end{array}$ \\
\hline $\begin{array}{l}\text { Controlling alien } \\
\text { fish species }\end{array}$ & $\begin{array}{l}\text { Alien fish plan, alien fish workshop, carp cages, } \\
\text { Gambusia control project, carp control projects }\end{array}$ & $\begin{array}{l}\text { Stuart \& Jones (2006), Stuart et al. (2006), Ansell \& } \\
\text { Jackson (2007), Thresher (2008), Macdonald \& } \\
\text { Tonkin (2008), Thwaites et al. (2010), } \\
\text { Anon (2011), Smith et al. (2011) }\end{array}$ \\
\hline $\begin{array}{l}\text { Managing fish } \\
\text { translocation } \\
\text { and stocking }\end{array}$ & $\begin{array}{l}\text { Stocking and translocation workshop, stocking } \\
\text { review, genetics workshop, marking } \\
\text { stocked native fish, }\end{array}$ & $\begin{array}{l}\text { Phillips (2003), Gillanders et al. (2006), } \\
\text { Crook et al. (2009, 2011), Moore et al. (2010), } \\
\text { Woodcock et al. (2011) }\end{array}$ \\
\hline $\begin{array}{l}\text { Protecting } \\
\text { threatened native } \\
\text { fish species }\end{array}$ & $\begin{array}{l}\text { Murray cod management workshop, } \\
\text { establishment of Murray cod taskforce, Murray } \\
\text { cod recovery plan, Murray cod population model, } \\
\text { Murray crayfish knowledge review, emergency } \\
\text { response workshop, training stocked threatened } \\
\text { fish project, recreational fishing workshop }\end{array}$ & $\begin{array}{l}\text { Bearlin \& Tikel (2003), Todd et al. (2004), } \\
\text { Lintermans \& Phillips (2005), Gilligan et al. } \\
\text { (2007), Todd (2009), Todd \& Koehn (2009), } \\
\text { Hutchison et al. (2011) }\end{array}$ \\
\hline $\begin{array}{l}\text { Community } \\
\text { engagement }\end{array}$ & $\begin{array}{l}\text { Native fish awareness week, Community } \\
\text { Stakeholder Taskforce, annual fish forums, } \\
\text { 'Talking fish' booklets for } 11 \text { rivers }\end{array}$ & $\begin{array}{l}\text { Lintermans (2008), Pritchard (2009), Anon } \\
\text { (2011), Murray-Darling Basin Authority } \\
\text { (2011b), Trueman (2011) }\end{array}$ \\
\hline $\begin{array}{l}\text { Knowledge } \\
\text { generation } \\
\text { and transfer }\end{array}$ & $\begin{array}{l}11 \text { workshops }{ }^{\mathrm{a}} \text { : weirs, thermal pollution, } \\
\text { translocations and stocking, habitat } \\
\text { rehabilitation, Murray cod, downstream } \\
\text { migration, wetlands, emergency responses, } \\
\text { drought, alien species, genetics; research } \\
\text { projects and publications; NFS coordinators; } \\
\text { native fish awareness week; information } \\
\text { sheets, Murray-Darling Basin fish book }\end{array}$ & $\begin{array}{l}\text { Phillips (2001, 2003, 2006), Inland Rivers Network } \\
\text { (2001), Lintermans \& Cottingham (2007), } \\
\text { Lintermans \& Phillips (2004, 2005), } \\
\text { Lintermans et al. (2005), Ansell \& Jackson } \\
\text { (2007), Lintermans (2007), Moore et al. (2010) }\end{array}$ \\
\hline
\end{tabular}

A major on-ground success has been the Sea to Hume fish passage program - a world-class system of fishways to provide fish passage along $2225 \mathrm{~km}$ of the Murray River between the Murray mouth and the Hume Dam at Albury (Barrett \& Mallen-Cooper 2006) (Fig. 1). Commenced in 2001, and with a construction cost of \$AUD 45 million, the program will be completed in 2011/2012 and aims to provide fish passage past 15 weirs and barrages by constructing a range of fishway designs. In addition to providing fish passage, this program contributed significantly to improved knowledge of fish movements and fishway design, due largely to a multi-disciplinary team (biologists, engineers and operational staff) working together (Barrett 2008).

The reinstatement of structural instream habitats (e.g. large wood) is a key paradigm shift in MDB river management (Nicol et al. 2002, 2004). Development of an adaptive management process for environmental water allocations (King et al. 2010), 
together with an increased scientific understanding of the benefits for fish (King et al. 2007, 2009) has also been significantly improved through NFS investments (Table 4).

Another key achievement of the NFS is the concept and establishment of demonstration reaches, where a series of restorative actions can be used to illustrate the value of integrated action on multiple threats in a river reach (Barrett \& Ansell 2005). This is in contrast to the traditional approach to management with a focus on single species or regional interventions (e.g. installing barriers to prevent access by trout species to barred galaxias habitats; Raadik et al. 2010). Demonstration reaches are prominent (close to population centres), substantial ( 20 to $100 \mathrm{~km}$ in length) and longer term (e.g. $>5 \mathrm{yr}$ ) initiatives, useful for integrating all relevant land and water programs into a comprehensive rehabilitation plan that uses the principles of adaptive management. They provide an excellent mechanism for improving public awareness, understanding, participation and support for habitat rehabilitation and the protection of native fishes. Seven demonstration reaches have now been established across the MDB covering almost $800 \mathrm{~km}$ of river (Murray-Darling Basin Authority 2011a). All demonstration reaches require the design and implementation of a rigorous monitoring program (Boys et al. 2008), with the intent that activities in demonstration reaches become self-sustaining after initial seedfunding from the NFS.

A key benefit of the NFS and its Advisory Panel is the ability to react to emerging issues. Key examples of this include the establishment of a drought expert panel (Lintermans \& Cottingham 2007), as the 'millennium drought' (1997 to 2010) progressed (Bond et al. 2008, Murphy \& Timbal 2008) and caused major management issues in the MDB (Pratchett et al. 2011), and the establishment of a fund for emergency responses (such as the rescue of threatened native populations from drying rivers or at-risk habitats) (see Pritchard et al. 2009). The NFS Advisory Panel also performs the role of knowledge broker or 'gatekeeper' between the MDBA and state agencies, a critical role if public sector agencies is to adopt new knowledge (Murray et al. 2011).

\section{EVALUATION OF THE NFS}

The NFS is a new approach to the rehabilitation of fish populations, and so needs to be regularly reviewed to assess its effectiveness. Consequently, an independently conducted review after 5 yr was incorporated into the original NFS program design (Cottingham et al. 2009). Utilising the outcomes of this review and additional analysis, the strengths, weaknesses, opportunities and threats to the NFS have been identified and are summarised in Box 1.

The long-term nature of the NFS (50 yr) and its whole-of-basin, multi-disciplinary basis are major strengths of the program. Another strength of the NFS is its oversight by the collaborative expert Advisory Panel which allows the identification, prioritisation and then funding of research investigations, facilitating targeted investigations that can readily and rapidly be transferred into management and policy outcomes. The NFS provides opportunities for improved communication and partnerships with key stakeholders, such as angling and community groups, incorporating indigenous culture and values and securing increased public and political profile and support for fish and river health.

The long-term nature of the NFS can be a doubleedged sword, with changes in governments, their priorities and lack of 'newness or novelty value' perceived by some as potential threats over time. A long-term 'champion' for the NFS would assist in maintaining a public profile and guard against complacency. It is not just the NFS that is potentially threatened by a long-term drift in priorities, but closely allied programs such as the SRA, which provides the mechanism for measuring recovery in fish condition. The NFS must continue to be integrated with and support allied programs such as the SRA, if progress toward the overall goal is to be measured. The lack of progress in achieving milestones or benchmarks to measure recovery towards the overall goal of $60 \%$ pre-European fish condition is a current weakness, not given sufficient attention in the original NFS. Interim targets are now being developed (Murray-Darling Basin Authority 2011a), but care must be taken to ensure that any measures of progress are realistic, recognising that initial progress is likely to be slow.

As with any NRM program, demands and needs outnumber resources, but it is informative to review where the gaps occur. Strategic actions devoted to threatened species recovery have possibly received less attention than deserved in the first $5 \mathrm{yr}$ of the NFS, although the millennium drought did precipitate a number of emergency responses through the NFS (Guzman et al. 2007). It could be argued that other commonwealth and state agencies (see www.environment.gov.au/biodiversity/threatened) have primary responsibility for threatened species recovery and so the NFS should play a supporting 
Box 1. Evaluation (strengths, weaknesses, opportunities and threats) of the Native Fish Strategy (NFS). MDBA: MurrayDarling Basin Authority

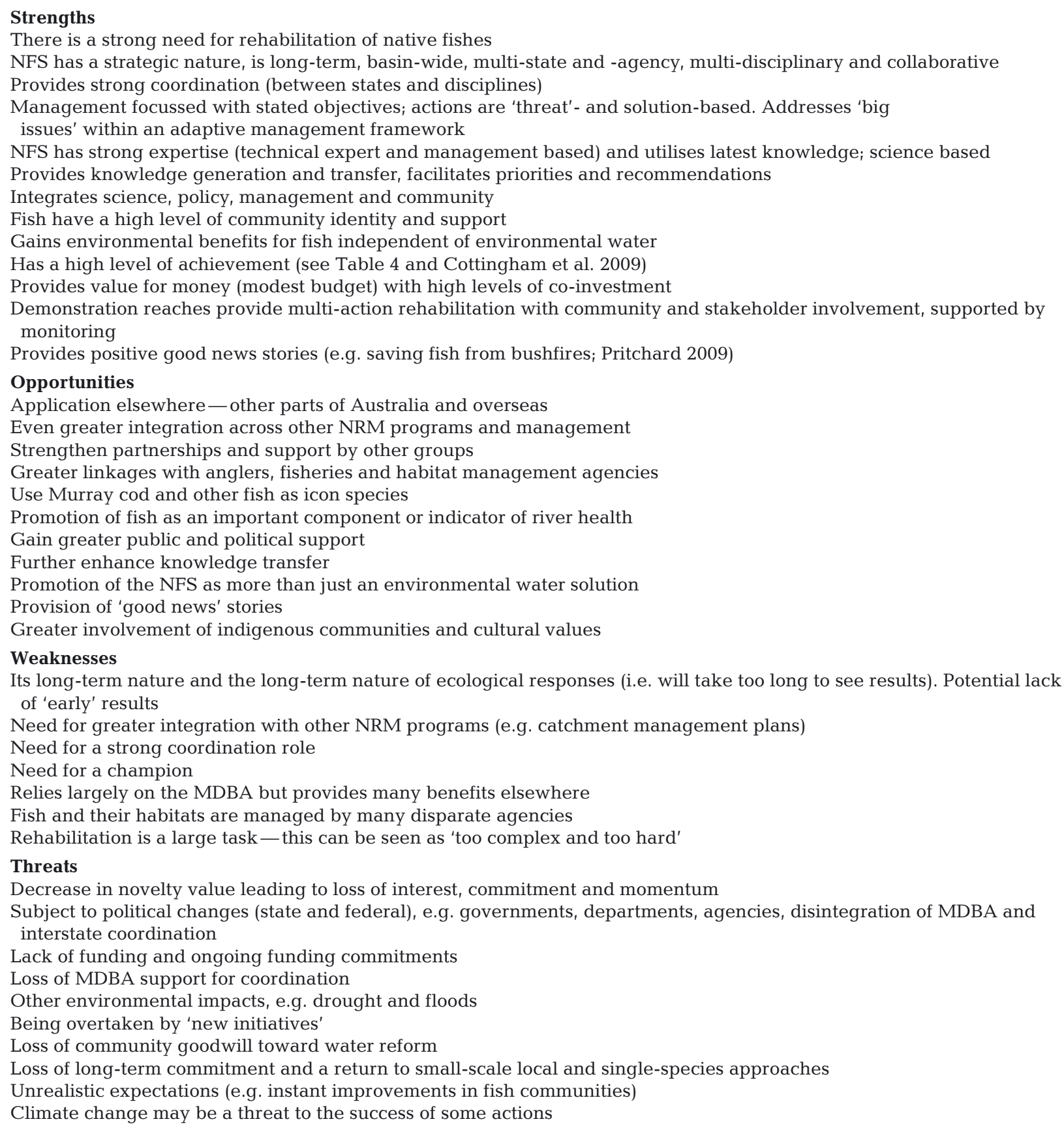

role and concentrate on remediation of threatening processes. Similarly, there has been limited focus on fish disease issues and management through the NFS, although recent investigations (Whittington et al. 2010) and the development of a standard fish kill investigation protocol have provided some impetus for further action. Coldwater pollution is a major water quality impact for which the NFS has been unable to gain significant traction (Phillips 2001), largely as a result of the high cost of remediation. Some jurisdictions have made significant progress (Boys et al. 2009, Raine et al. 2009) through incorporation of multi-level off-takes, but, elsewhere, onground implementation of remediation actions 
remains elusive. Another omission is the lack of onground implementation in the MDB and, nationally, of a system of freshwater protected areas (FPAs) (Nevill 2007). The need for an Australian system of FPAs was identified a decade ago (Georges \& Cottingham 2002, Nevill \& Phillips 2002, Beumer et al. 2003), yet little on-ground progress has been made (Barmuta et al. 2011). While a model for FPAs in the basin has been developed (Phillips \& Butcher 2005, Phillips 2008), it has not been implemented as there is a bit of misconceived nervousness by some stakeholders about 'locking up' rivers.

In an assessment of the NFS, a useful question to ask is: Where would we be without it?

- There would be no Sea to Hume fish passage program, and sub-optimal fishway designs for other locations (see Barrett \& Mallen-Cooper 2006, Barrett 2008)

- Allocation of environmental water to rivers and floodplains would be largely uninformed with regard to fish needs and likely responses (see King et al. 2007, 2009, 2010)

- The large numbers of fish extracted by irrigation infrastructure (pumps and diversion channels), and the significant mortality of fish and larvae passing over weirs, would have remained unrecognised and unquantified (see Lintermans \& Phillips 2004, Baumgartner et al. 2009, 2010)

- The design of habitat interventions such as the addition of Structural Woody Habitats would have remained ad hoc (see Nicol et al. 2002, 2004, Koehn et al. 2004a)

- There would be few robust examples of rigorous monitoring to allow for adaptive management for freshwater fish (see Barrett \& Mallen-Cooper 2006, Barrett 2008, King et al. 2010)

- The community would be largely uninformed, uninterested and uninvolved in native fish problems and solutions (see Lintermans 2007, Pritchard 2009, native fish forums, Native Fish Awareness Week)

- Anglers would be alienated through lack of consultation or involvement in fish management (see Lintermans \& Phillips 2005, Murray Cod Taskforce)

- There would be no capacity to measure natural fish recovery (distinguish stocked fish from wild fish) (see Crook et al. 2009, 2011, Woodcock et al. 2011).

- Threatened fish species recovery would still be conducted mainly on a species-by-species basis (i.e. single-species recovery plans).

The NFS provides an effective partnership model where central coordination and focused actions can deliver value-added benefits to all jurisdictional governments. It can synthesise knowledge, integrate research and management and catalyse actions for pri- ority problems. A key feature has been the recognition that multiple interventions to address a number of threats to native fish populations, rather than single solutions, can have a greater chance of achieving improved ecological outcomes. This NFS has, with its partners, established demonstration reaches as a vehicle to promote this concept, also providing an avenue to elicit community and stakeholder ownership and focus investment in rehabilitation. The capacity of demonstration reaches to continue without NFS funding in the future will be an important issue for the NFS.

Some achievements of the NFS also address larger, more intractable problems that are unlikely to have been undertaken by individual jurisdictions alone. The concept of a NFS has already been expanded and transferred outside the MDB in 'A guide to the management of native fish: Victorian coastal rivers, estuaries and wetland' (Drew 2008), and this approach would be suitable for many large river basins throughout the world, particularly those where multiple jurisdictions are involved.

\section{WHERE TO FROM HERE?}

In response to the degraded nature of rivers and ecosystems, new national legislation (Water Act 2007) was introduced to regulate water usage in the MDB. This legislation dictates the development of a 'Basin Plan' to address over-allocation and overuse of existing water resources and find a balance that optimises economic, social and environmental outcomes (Murray-Darling Basin Authority 2010). In response to this changed water management framework, and building on the NFS 5 yr review (Cottingham et al. 2009), a new 10 yr action plan has been drafted to guide the activities in the next phase of the NFS. The 'NFS Action Plan 2011-2021' (Murray-Darling Basin Authority 2011a) has been designed to build on the early achievements of the NFS and help deliver its long-term objectives. It continues with the original NFS philosophy and driving actions, but has reviewed and refocused them toward 5 key areas: (1) fish-friendly infrastructure and water management, (2) connecting with communities (especially anglers), (3) protecting the icons of the basin, (4) controlling alien fish species and (5) building new knowledge. To ensure that progress can be measured and implementation of the NFS Action Plan is successful, clear targets have been developed against which performance will be assessed. These include 5 yr management action targets ('Did we do what we said we were going to do?') and 10 yr resource condition tar- 
gets ('Did our actions make a difference?') (MurrayDarling Basin Authority 2011a). Most of the management action targets are ambitious targets (e.g. $3900 \mathrm{~km}$ of additional fish passage achieved, no new incursions of pest fish species, $1000 \mathrm{~km}$ of additional demonstration reaches established in 8 new catchments) that are intended to galvanise additional effort to rehabilitate native fish populations.

Twenty-seven priority actions have been identified (Murray-Darling Basin Authority 2011a), but significant resources will be required to implement them, far more than was provided under the first stage of the NFS. The recognition of the national importance of the basin's poor condition and its elevated prominence through the Water Act 2007 may provide new funding options and real hope that the required level of investment will be delivered.

Future priority issues also include:

- The need to clearly identify and facilitate onground implementation of research project outcomes - Continued and expanded dissemination of information to communities

- How to leverage additional funding for 'big ticket' interventions such as provision of environmental water and mitigation of thermal pollution

- Implementation of a system of freshwater protected areas

- Planning for the likely impacts of climate change (Balcombe et al. 2011, Koehn et al. 2011, Morrongiello et al. 2011, Pratchett et al. 2011), including embedding lessons from the 'millennium drought' into regular management of aquatic resources (e.g. concepts of resistance, resilience and protection of refugia)

- Coordination and implementation of alien fish management

Within the Action Plan (Murray-Darling Basin Authority 2011a) there is a greater emphasis on the engagement of the community, and in particular recreational anglers, as there are obvious and significant social and economic advantages to the recreational fishing and tourism industries through having healthy fish populations. Particular attention is also paid to the coordination of the cross-jurisdictional management of Murray cod, both as an icon and a threatened species. This has already resulted in a more integrated approach to its management for conservation and recreational angling (Department of Primary Industries 2010, Koehn 2010, National Murray Cod Recovery Team 2010, Department of Primary Industries 2011). This provides an example of integrated species management for multiple values.

Justification for management decisions in aquatic environments, especially the allocation of environ- mental water (see King et al. 2007, 2009, 2010) are coming under increasing scrutiny and highlight the continued need for appropriate supporting research (capacity and funding). Many NFS actions provide ecological benefits that are independent of water allocations that can be difficult to achieve. Healthy fish populations would also increase community 'connectedness' to the river and help bring indigenous cultural values into the mainstream. The improved status of native fish populations in the MDB will be the key criterion by which the public will judge the success of this strategy and also water management in general in the MDB.

\section{CONCLUSIONS}

The NFS for the MDB provides a substantial shift in the restoration and conservation of native fish in Australia through a whole-of-fish-community approach. It provides a model for a coordinated approach across jurisdictional boundaries that addresses key threats within an adaptive management framework, is supported by new knowledge and encourages community ownership. The strategy is long term (50 yr), but operationalised as a series of $10 \mathrm{yr}$ 'action plans'. The NFS introduces a management structure which includes a policy/scientific Advisory Panel and a community stakeholder taskforce encompassing representatives of many stakeholder groups, including indigenous peoples, which have always had strong spiritual and physical connections with the environment. This whole-of-fish-community approach and coordinated direction of recovery actions could be used in the restoration of fish populations in other large river systems around the world.

Acknowledgements. The authors thank Don Blackmore for his foresight with regards to the Native Fish Strategy, Brian Lawrence, Jim Barrett and the Murray-Darling Basin Commission (now Authority) NFS team, Simon Nicol (a co-author of the NFS with J.D.K.), NFS coordinators and advisory panel members and all those who have funded and supported this vision for rehabilitating native fishes. A full version of the 'Native Fish Strategy' is available at www.mdba.gov.au. Comments on this manuscript were kindly provided by Pam Clunie, Dean Ansell and the anonymous reviewers.

\section{LITERATURE CITED}

Allen GR, Midgley SH, Allen M (2002) Field guide to the freshwater fishes of Australia. Western Australian Museum, Perth, and CSIRO Publishing, Collingwood

Anon (2011) Stop the spread. Tilapia training package. The State of Queensland, Dept of Employment, Economic Development and Innovation, Brisbane 
Ansell D, Jackson P (eds) (2007) Emerging issues in alien fish management in the Murray-Darling Basin: statement, recommendations and supporting papers. Proceedings of a workshop held in Brisbane, QLD, 30-31 May 2006. MDBC Publication No. 16/07, Murray-Darling Basin Commission, Canberra

Arthington AH, Pusey BJ (2003) Flow restoration and protection in Australian rivers. River Res Appl 19:377-395

Balcombe SR, Sheldon F, Capon SJ, Bond NR, Hadwen WL, Marsh N, Bernays SJ (2011) Climate change in context: Flow regulation and climate threats in the MurrayDarling Basin? Mar Freshw Res 62:1099-1114

> Barmuta LA, Linke S, Turak E (2011) Bridging the gap between 'planning' and 'doing' for biodiversity conservation in freshwaters. Freshw Biol 56:180-195

Barrett J (2004) Introducing the Murray-Darling Basin Native Fish Strategy and initial steps toward demonstration reaches. Ecol Manag Restor 5:15-23

Barrett J (ed) (2008) The sea to Lake Hume: restoring fish passage in the Murray River. MDBC Publication No. 32/08, Murray-Darling Basin Commission, Canberra

Barrett J, Ansell D (2003) The practicality and feasibility of establishing a system of freshwater protected areas in the Murray-Darling Basin. In: Beumer JP, Grant A, Smith DC (eds) Aquatic protected areas: What works best and how do we know? Proceedings of the World Congress on aquatic protected areas, Cairns, Australia, August 2002. University of Queensland Printery, St Lucia, p 601-613

Barrett J, Ansell D (2005) Demonstration reaches for native fish: moving from theory to practice. In: Rutherfurd ID, Wiszniewski I, Askey-Doran M, Glazik R (eds) Proceedings of the 4th Australian Stream Management Conference: linking rivers to landscapes. Department of Primary Industries, Water and Environment, Hobart, p 59-67

Barrett J, Mallen-Cooper M (2006) The Murray River's 'Sea to Hume Dam' fish passage program: progress to date and lessons learned. Ecol Manag Restor 7:173-183

Baumgartner LJ, Reynoldson N, Cameron L, Stanger J (2006a) Assessment of a dual-frequency identification sonar (DIDSON) for application in fish migration studies. Fisheries Final Report Series No. 84, NSW Department of Primary Industries, Sydney

Baumgartner LJ, Reynoldson N, Gilligan DM (2006b) Mortality of larval Murray cod (Maccullochella peelii peelii) and golden perch (Maquaria ambigua) associated with passage through two types of low-head weirs. Mar Freshw Res 57:187-191

Baumgartner LJ, Reynoldson NK, Cameron L, Stanger J (2009) Effects of irrigation pumps on riverine fish. Fish Manag Ecol 16:429-437

Baumgartner L, McPherson B, Doyle J, Cory F, Cinotti N, Hutchison J (2010) Quantifying and mitigating the impacts of weirs on downstream passage of native fish in the Murray-Darling Basin. Report to Murray-Darling Basin Authority, NSW Department of Industry and Investment, Sydney

Bearlin AR, Tikel D (2003) Conservation genetics of MurrayDarling basin fish; silver perch (Bidyanus bidyanus), Murray cod (Maccullochella peelii) and trout cod ( $M$. macquariensis). In: Phillips BF (ed) Managing fish translocation and stocking in the Murray-Darling Basin. Statement, recommendations and supporting papers. Workshop held in Canberra, 25-26 September 2002. WWF Australia, Sydney, p 59-83
Berghuis A (2008) Performance of a single frequency split beam hydroacoustic system: an innovative fish counting technology. Arthur Rylah Institute for Environmental Research Technical Report Series No. 177, Department of Sustainability and Environment, Heidelberg, VIC

Bernhardt ES, Palmer MA, Allan JD, Alexander G and others (2005) Synthesizing U.S. river restoration efforts. Science 308:636-637

Beumer JP, Grant A, Smith DC (eds) (2003) Aquatic protected areas: What works best and how do we know? Proceedings of the World Congress on aquatic protected areas, Cairns, Australia, August 2002. University of Queensland Printery, St Lucia, QLD

Bond NR, Lake PS, Arthington AH (2008) The impacts of drought on freshwater ecosystems: an Australian perspective. Hydrobiologia 600:3-16

Boys CA, Robinson W, Butcher A, Zampatti B, Lyon J (2008) Framework for developing and implementing ecological monitoring and evaluation of aquatic rehabilitation in demonstration reaches. MDBC Publication No. 43/08, Murray-Darling Basin Commission, Canberra

Boys C, Miles N, Rayner T (2009) Scoping options for the ecological assessment of cold water pollution mitigation downstream of Keepit Dam, Namoi River. MDBA Publication No. 20/09, Murray-Darling Basin Authority, Canberra

Cadwallader PL (1977) J. O. Langtry's 1949-50 Murray River investigations. Fisheries and Wildlife Paper, Victoria No. 13, Fisheries and Wildlife Dept., Melbourne

Cadwallader PL (1978) Some causes of the decline in range and abundance of native fish in the Murray-Darling River System. Proc R Soc Vic 90:211-224

Cadwallader PL, Gooley GJ (1984) Past and present distributions and translocations of Murray cod Maccullochella peeli and trout cod M. macquariensis (Pisces: Percichthyidae) in Victoria. Proc R Soc Vic 96:33-43

Close A (1990) The impact of man on the natural flow. In: Mackay N, Eastburn D (eds) The Murray. MurrayDarling Basin Commission, Canberra, p 61-77

Clunie P, Koehn J (2001a) Silver perch: a recovery plan. Final report for project R8002, Murray-Darling Basin Commission, Canberra

Clunie P, Koehn J (2001b) Freshwater catfish: a recovery plan. Final report for project R8002, Murray-Darling Basin Commission, Canberra

Clunie P, Ryan T, James K, Cant B (2002) Implications for rivers from salinity hazards: scoping study. Report produced for Murray-Darling Basin Commission, Strategic Investigations and Riverine Program-Project R2003. Department of Natural Resources and Environment, Heidelberg

Cottingham P, Bond N, Hart B, Lake S, Reich P (2009) The Murray-Darling Basin Native Fish Strategy: 5th year review. Report by Peter Cottingham \& Associates in collaboration with Monash University and Water Science Pty, Melbourne

Cowx IG, Welcomme RL (eds) (1998) Rehabilitation of rivers for fish. FAO and Fishing News Books, Blackwell Science Ltd, Oxford

Crook DA, O'Mahony D, Sanger AC, Munro AR, Gillanders BM, Thurstan S (2009) Development and evaluation of methods for osmotic induction marking of golden perch (Macquaria ambigua) with calcein and alizarin red S. North Am J Fish Manag 29:279-287

Crook DA, Gillanders BM, Sanger AC, Munro AR and oth- 
ers (2011) Methods for discriminating hatchery fish and outcomes of stocking in the Murray-Darling Basin. Final Report for Project MD741 to the Murray-Darling Basin Authority. Arthur Rylah Institute for Environmental Research, Heidelberg, VIC

Davies PE, Harris JH, Hillman TJ, Walker KF (2008) SRA Report 1: a report on the ecological health of rivers in the Murray-Darling Basin, 2004-2007. Prepared by the Independent Sustainable Rivers Audit Group for the MurrayDarling Basin Ministerial Council, Murray-Darling Basin Commission, Canberra

Davies PE, Harris JH, Hillman TJ, Walker KF (2010) The Sustainable Rivers Audit: assessing river ecosystem health in the Murray-Darling Basin, Australia. Mar Freshw Res 61:764-777

Department of Primary Industries (2010) Enhancing the Murray cod recreational fishery. A basin-wide approach to research and management. Summary of workshop, 22-23 February 2010. Department of Primary Industries, Melbourne

Department of Primary Industries (2011) Draft terms of reference. Murray cod fishery management group, Department of Primary Industries, Melbourne

Drew MM (2008) A guide to the management of native fish: Victorian coastal rivers, estuaries and wetlands. Department of Sustainability and Environment and the Corangamite Catchment Management Authority, Melbourne

DSE (Department of Sustainability and Environment) (2007) Advisory list of threatened vertebrate fauna in Victoria2007. DSE, East Melbourne. Available at: www.dse.vic. gov.au/plants-and-animals/native-plants-and-animals/ threatened-species-and-communities/threatened-speciesadvisory-lists (accessed 20 May 2011)

Dudgeon D, Arthington AH, Gessner MO, Kawabata Z and others (2006) Freshwater biodiversity: importance, threats, status and conservation challenges. Biol Rev Camb Philos Soc 81:163-182

Garcia N, Cuttelod A, Abdul Malak D (eds) (2010) The status and distribution of freshwater biodiversity in northern Africa. IUCN, Gland

Georges AP, Cottingham P (2002) Biodiversity in inland waters - priorities for its protection and management: recommendations from the 2001 Fenner Conference on the environment. Technical Report 2002, Cooperative Research Centre for Freshwater Ecology, Canberra

Gillanders B, Elsdon T, Munro A (2006) Impacts of native fish stocking on fish within the Murray-Darling Basin. Final report for MDBC Contract No. MD239, University of Adelaide, Adelaide

Gilligan D, Schiller C (2003) Downstream transport of larval and juvenile fish in the Murray River. NSW Fisheries Final Report Series No. 50, NSW Fisheries, Narrandera

Gilligan D, Rolls R, Merrick J, Lintermans M, Duncan P, Kohen J (2007) Scoping the knowledge requirements for Murray crayfish (Euastacus armatus). Final report to Murray-Darling Basin Commission for Project No. 05/1066, Fisheries Final Report Series No. 89, NSW Department of Primary Industries, Cronulla

Guzman I, Higham J, Hall A (2007) 2007 Native fish emergency response workshop. Summary, abstract and recommendations. Proceedings of a workshop held in Adelaide, SA, 21-22 November 2007. Dept Environment and Natural Resources, Adelaide, SA (draft)

Hammer M, Wedderburn S, Van Weenen J (2009) Action plan for South Australian freshwater fishes. Native Fish Australia (SA), Adelaide

Harris JH (1995) The use of fish in biological assessments. Aust J Ecol 20:65-80

Harris JH, Gehrke PC (eds) (1997) Fish and rivers in stress. The NSW Rivers Survey. NSW Fisheries, Cooperative Research Centre for Freshwater Ecology and Resource and Conservation Assessment Council, Sydney

Henry GW, Lyle JM (eds) (2003) The national recreational and indigenous fishing survey. NSW Fisheries Final Report Series No. 48, NSW Fisheries, Sydney

Hutchison M, Butcher A, Kirkwood J, Mayer D, Chikott K, Backhouse S (2008) Mesoscale movements of small and medium-sized fish in the Murray-Darling Basin. MDBC Publication No. 41/08, Murray-Darling Basin Commission, Canberra

Hutchison M, Stewart D, Chilcott K, Butcher A and others (2011) Strategies to improve post release survival of hatchery-reared threatened fish species. Murray-Darling Basin Authority, Canberra

Inland Rivers Network (comp) (2001) The proceedings of The Way Forward on Weirs. Presented on 18-19 August 2000, at the Centenary Lecture Theatre, Royal North Shore Hospital, St. Leonards, NSW. Inland Rivers Network, Sydney

Jelks HL, Walsh SJ, Burkhead NM, Contreras-Balderas S and others (2008) Conservation status of imperilled North American freshwater and diadromous fishes. Fisheries 33:372-407

Jones M (2006) Effects of environmental flow allocations on the lateral movements of native fish in the BarmahMillewa Forest. Final report to the Murray-Darling Basin Commission, Arthur Rylah Institute for Environmental Research, Heidelberg

Jones MJ, Stuart IG (2004) Impact of flow regulation structures on fish in the Barmah-Millewa forest. Final report for the Barmah-Millewa Forum, Arthur Rylah Institute for Environmental Research, Heidelberg

Jones MJ, Stuart IG (2008) Regulated floodplains - a trap for unwary fish. Fish Manag Ecol 15:71-79

King AJ, O'Connor JP (2007) Native fish entrapment in irrigation systems: a step towards understanding the significance of the problem. Ecol Manag Restor 8:32-38

King AJ, Tonkin Z, Mahoney JM (2007) Assessing the effectiveness of environmental flows on fish recruitment in Barmah-Millewa Forest. Report to Murray-Darling Basin Commission, Arthur Rylah Institute for Environmental Research, Department of Sustainability and Environment, Melbourne, VIC

> King AJ, Tonkin Z, Mahoney J (2009) Environmental flows enhance native fish spawning and recruitment in the Murray River, Australia. River Res Appl 25:1205-1218

> King AJ, Ward KA, O'Connor P, Green D, Tonkin Z, Mahoney J (2010) Adaptive management of an environmental watering event to enhance native fish spawning and recruitment. Freshw Biol 55:17-31

Kingsford RT (2000) Ecological impacts of dams, water diversions and river management on floodplain wetlands in Australia. Austral Ecol 25:109-127

Koehn J (2001) The impacts of weirs on fish. In: The proceedings of The Way Forward on Weirs. Presented on 18-19 August 2000, at the Centenary Lecture Theatre, Royal North Shore Hospital, St. Leonards, NSW. Inland Rivers Network, Sydney, p 59-66

> Koehn JD (2004a) Rehabilitating fish habitats in Australia: 
improving integration of science and management by agencies and the community. Ecol Manag Restor 5: 211-213

Koehn JD (2004b) Carp (Cyprinus carpio) as a powerful invader in Australian waterways. Freshw Biol 49:882-894

Koehn J (2010) Conservation and utilisation: harnessing forces for better outcomes for native fishes. Ecol Manag Restor 11:86-87

Koehn JD, O'Connor WG (1990) Threats to Victorian native freshwater fish. Vict Nat 107:5-12

Koehn JD, Nicol SJ, Fairbrother PS (2004a) Spatial arrangements and physical characteristics of structural woody habitat in a lowland river in south-eastern Australia. Aquat Conserv Mar Freshw Ecosyst 14:457-464

Koehn J, Stuart I, Crook D (2004b) Linking the ecological importance of downstream fish movements to management of Murray-Darling Basin fish populations. In: Lintermans M, Phillips B (eds) Downstream movement of fish in the Murray-Darling Basin-Statement, recommendations and supporting papers. Workshop held in Canberra, 3-4 June 2003: Murray-Darling Basin Commission, Canberra, p 67-78

> Koehn JD, Hobday AJ, Pratchett MS, Gillanders BM (2011) Climate change and Australian marine and freshwater environments, fishes and fisheries: synthesis and options for adaptation. Mar Freshw Res 62:1148-1164

Lawrence BW (1991) Fish management plan. MurrayDarling Basin Commission, Canberra

Likens GE, Walker KF, Davies PE, Brookes J and others (2009) Ecosystem science: toward a new paradigm for managing Australia's inland aquatic ecosystems. Mar Freshw Res 60:271-279

Lindenmayer DB, Likens GE (2009) Adaptive monitoring: a new paradigm for long-term research and monitoring. Trends Ecol Evol 24:482-486

Lindenmayer DB, Likens GE (2010) The science and application of ecological monitoring. Biol Conserv 143: 1317-1328

Lintermans M (2007) Fishes of the Murray-Darling Basin: an introductory guide. Murray-Darling Basin Commission, Canberra

Lintermans M (ed) (2008) Proceedings of the MurrayDarling Basin Commission Native Fish Strategy Forum 2007. MDBC Publication No. 02/08, Murray-Darling Basin Commission, Canberra

Lintermans M (2010) Conservation status of Australian fishes - 2010. Aust Soc Fish Biol Newsl 40:79-82

Lintermans M, Cottingham P (eds) (2007) Fish out of water-lessons for managing native fish during drought. Final Report of the Drought Expert Panel, Murray-Darling Basin Commission, Canberra

Lintermans M, Phillips B (eds) (2004) Downstream movement of fish in the Murray-Darling Basin. Statement, recommendations and supporting papers from a workshop held in Canberra, 3-4 June 2003. Murray-Darling Basin Commission, Canberra

Lintermans M, Phillips B (eds) (2005) Management of Murray cod in the Murray-Darling Basin: statement, recommendations and supporting papers. Proceedings of a workshop held in Canberra, ACT, 3-4 June 2004. Murray-Darling Basin Commission, Canberra

Lintermans M, Cottingham P, O'Connor R (eds) (2005) Native fish habitat rehabilitation and management in the Murray-Darling Basin: statement, recommendations and supporting papers. Proceedings of a workshop held in
Albury, NSW, 10-11 February 2004. Murray-Darling Basin Commission and Cooperative Research Centre for Freshwater Ecology, Canberra

Lyon JP, O'Connor JP (2008) Smoke on the water: Can riverine fish populations recover following a catastrophic firerelated sediment slug? Austral Ecol 33:794-806

Macdonald J, Tonkin Z (2008) A review of the impact of eastern gambusia on native fishes of the Murray-Darling Basin. Arthur Rylah Institute for Environmental Research, Department of Sustainability and Environment, Heidelberg, Victoria. MDBA Publication No. 38/09, Murray-Darling Basin Authority, Canberra

- Malmqvist B, Rundle S (2002) Threats to the running water ecosystems of the world. Environ Conserv 29:134-153

Moore A, Ingram BA, Friend S, King Ho H and others (2010) Management of genetic resources for fish and crustaceans in the Murray-Darling Basin. Bureau of Rural Sciences, Canberra

Morrongiello JR, Beatty SJ, Bennett JC, Crook DA and others (2011) Climate change and its implications for Australia's freshwater fish. Mar Freshw Res 62:1082-1098

> Murphy BF, Timbal B (2008) A review of recent climate variability and climate change in southeastern Australia. Int J Climatol 28:859-879

> Murray K, Roux D, Nel J, Driver A, Freimund W (2011) Absorptive capacity as a guiding concept for effective public sector management and conservation of freshwater ecosystems. Environ Manag 47:917-925

Murray-Darling Basin Authority (2010) Guide to the proposed Basin Plan: overview. Murray-Darling Basin Authority, Canberra

Murray-Darling Basin Authority (2011a) The Murray-Darling Basin native fish strategy action plan for 2011-2021. Murray-Darling Basin Authority, Canberra

Murray-Darling Basin Authority (2011b) Goulburn. Talking fish. Making connections with the rivers of the MurrayDarling Basin. Murray-Darling Basin Authority, Canberra

Murray-Darling Basin Commission (2002) Draft native fish strategy for the Murray-Darling Basin. Murray-Darling Basin Commission, Canberra

Murray-Darling Basin Commission (2004) Native fish strategy for the Murray-Darling Basin 2003-2013. MurrayDarling Basin Commission, Canberra. Available at http: //www2.mdbc.gov.au/NFS.html (accessed 3 Apr 2011)

National Murray Cod Recovery Team (2010) National recovery plan for the Murray cod Maccullochella peelii peelii. Department of Sustainability and Environment, Melbourne. Available at www.environment.gov. au/biodiversity/threatened/recovery-list-common.html (accessed 20 Sep 2011)

Nevill J (2007) Policy failure: Australian freshwater protected area networks. Aust J Environ Manag 14:35-47

Nevill L, Phillips N (2002) Representative freshwater reserves: better late than never. Water Sci Technol 45:145-154

Nicol S, Lieschke J, Lyon J, Hughes V (2002) Resnagging revolution. River rehabilitation through resnagging. Final report to Agriculture, Fisheries, Forestry Australia River Rehab program, Arthur Rylah Institute for Environmental Research, Melbourne

> Nicol SJ, Lieschke J, Lyon J, Koehn JD (2004) Observations on the distribution and abundance of carp and native fish, and their responses to a habitat restoration trial in the Murray River, Australia. NZ J Mar Freshw Res 38: $541-551$ 
Nicol S, Todd CR, Koehn JD, Lieschke J (2005) How can recreational angling regulations help meet the multiple objectives for the management of Murray cod populations? In: Lintermans M, Phillips B (eds) Management of Murray cod in the Murray-Darling Basin: statement, recommendations and supporting papers. Proceedings of a workshop held in Canberra, ACT, 3-4 June 2004. Murray-Darling Basin Commission and Cooperative Research Centre for Freshwater Ecology, Canberra, p 98-106. Available at http://publications.mdbc.gov.au/ (accessed 20 Sep 2011)

NLWRA (National Land and Water Resources Audit) (2001) Australian water resources assessment 2000. NLWRA, Canberra

Nock CJ, Ovenden JR, Butler GL, Wooden I, Moore A, Baverstock PR (2011) Population structure, effective population size and adverse effects of stocking in the endangered Australian eastern freshwater cod Maccullochella ikei. J Fish Biol 78:303-321

Nelson JS (2006) Fishes of the world, 4th edn. John Wiley and Sons, Hoboken, NJ

> O'Connor JP, O'Mahony DJ, O'Mahony JM (2005) Movement of Macquaria ambigua, in the Murray River, southeastern Australia. J Fish Biol 66:392-403

O'Connor JP, O'Mahony DJ, O'Mahony JM, Glenane TJ (2006) Some impacts of low and medium head weirs on downstream fish movement in the Murray-Darling Basin in southeastern Australia. Ecol Freshw Fish 15:419-427

Phillips B (ed) (2001) Thermal pollution of the Murray-Darling Basin waterways: statement, recommendations and supporting papers. Proceedings of a workshop held at Lake Hume, 18-19 June 2001. Inland Rivers Network and WWF Australia, Sydney

Phillips B (ed) (2003) Managing fish translocation and stocking in the Murray-Darling Basin: statement, recommendations and supporting papers. Proceedings of a workshop held in Canberra, 25-26 September 2002. WWF Australia, Sydney

Phillips B (ed) (2006) Native fish and wetlands in the Murray-Darling Basin: action plan, knowledge gaps and supporting papers. Proceedings of a workshop held in Canberra, ACT, 7-8 June 2005. MDBC Publication No. 20/06, Murray-Darling Basin Commission, Canberra

Phillips B (2008) Audit of freshwater protected areas of the Murray-Darling Basin and development of a Habitat Management Areas 'toolkit'. Final report to the MurrayDarling Basin Commission, Mainstream Consulting, Canberra

Phillips B, Butcher R (2005) River parks: building a system of 'Habitat Management Areas' across the Murray-Darling. An international and national review of freshwater 'protected areas' for conserving aquatic biodiversity and river health. Final report to Murray-Darling Basin Commission, Mainstream Consulting, Canberra

Pratchett MS, Bay LK, Gehrke PC, Koehn JD and others (2011) Contribution of climate change to habitat degradation and loss in Australia's aquatic ecosystems. Mar Freshw Res 62:1062-1081

Pritchard J (2009) (ed) Proceedings of the Murray-Darling Basin Authority Native Fish Forum 2009, 1-2 September 2009. Albury Entertainment Centre, Murray-Darling Basin Authority, Canberra

Pritchard J, Hammer M, Hall A, Lugg A and others (2009) Drought and threatened species. In: Pritchard J (ed) Proceedings of the Murray-Darling Basin Authority Native
Fish Forum 2009, 1-2 September 2009. Albury Entertainment Centre, Murray-Darling Basin Authority, Canberra, p 63-73

Puckridge JT, Sheldon F, Walker KF, Boulton AJ (1998) Flow variability and the ecology of large rivers. Mar Freshw Res 49:55-72

Pusey BJ, Kennard MJ, Arthington AH (2004) Freshwater fishes of north-eastern Australia. CSIRO Publishing, Collingwood

Raadik TA, Fairbrother PS, Smith SJ (2010) National Recovery Plan for the barred galaxias Galaxias fuscus. Department of Sustainability and Environment, Melbourne

Raine A, Hardwick L, Hill C, Mitrovic S and others (2009) Managing impacts from thermal pollution on NSW rivers: policy and practice. In: Proceedings of the Australian Water Association Specialty Conference: rivers and reservoirs, Canberra 2009. Australian Water Association, Sydney

Reid DD, Harris JH, Chapman DJ (1997) NSW inland commercial fishery data analysis. FRDC Project No. 94/027 report, New South Wales Fisheries, Sydney

Roni P, Hanson K, Beechie T, Pess G, Pollock M, Bartley DM (2005) Habitat rehabilitation for inland fisheries. Global review of effectiveness and guidance for rehabilitation of freshwater ecosystems. FAO Fish Tech Pap No. 484, Food and Agriculture Organization, Rome

Rowland SJ (2005) Overview of the history, fishery, biology and aquaculture of Murray cod (Maccullochella peelii peellii). In: Lintermans M, Phillips B (eds) Management of Murray cod in the Murray-Darling Basin: statement, recommendations and supporting papers. Proceedings of a workshop held in Canberra, ACT, 3-4 June 2004. Murray-Darling Basin Commission and Cooperative Research Centre for Freshwater Ecology, Canberra, p 38-61. Available at http://publications.mdbc.gov.au/ (accessed 20 Sep 2011)

Ryan T, Lennie R, Lyon J, O'Brien T (2003) Thermal rehabilitation of the southern Murray-Darling Basin. Final Report to Agriculture, Forestry, Fisheries Australia, MD 2001 FishRehab program, Department of Sustainability and Environment, Heidelberg

Sala OE, Chapin FS III, Armesto JJ, Berlow E and others (2000) Global biodiversity scenarios for the year 2010. Science 287:1770-1774

Sherman B, Todd CR, Koehn JD, Ryan T (2007) Modelling the impact and potential mitigation of cold water pollution on Murray cod populations downstream of Hume Dam, Australia. River Res Appl 23:377-389

SKM (Sinclair, Knight Mertz) (2003) Review of habitat associations of native fish in the Murray-Darling Basin. Report to the Murray-Darling Basin Commission Project R2105, Sinclair, Knight Mertz, Melbourne

Smith KG, Darwall WRT (compilers) (2006) The status and distribution of freshwater fish endemic to the Mediterranean Basin. IUCN, Gland

Smith B, Thwaites L, Hillyard K, Conallin A (2011) Evaluation of carp exclusion screens at wetland inlets: a project synthesis. Prepared by the South Australian Research and Development Institute (Aquatic Sciences) for the Murray-Darling Basin Authority, Canberra

Stuart IG, Jones MJ (2006) Movement of common carp, Cyprinus carpio, in a regulated lowland Australian river: implications for management. Fish Manag Ecol 13: 213-219

Stuart IG, Williams A, McKenzie J, Holt T (2006) Managing 
a migratory pest species: a selective trap for common carp. N Am J Fish Manag 26:888-893

Stuart IG, Zampatti BP, Baumgartner LJ (2008) Can a lowgradient vertical-slot fishway provide passage for a lowland river fish community? Mar Freshw Res 59:332-346

Stuart I, Smith M, Baumgartner L (2009) Counting MurrayDarling fishes by validating sounds associated with spawning. A final report to the Murray-Darling Basin Commission, MDBA Publication No. 17/09, MurrayDarling Basin Authority, Canberra

Thresher RE (2008) Autocidal technology for the control of invasive fish. Fisheries 33:114-121

Thwaites A, Smith BB, Decelis M, Fleer D, Conallin A (2010) A novel push trap element to manage carp (Cyprinus carpio L.): a laboratory trial. Mar Freshw Res 61:42-48

Todd CR (2009) Murray cod management model: an application of Essential. Arthur Rylah Institute for Environmental Research, Department of Sustainability and Environment, Heidelberg. Available at www.dse.vic.gov. au/ari/software (accessed 16 May 2011)

Todd CR, Koehn JD (2009) Murray cod modelling to address key management actions: final report for project MD745. Arthur Rylah Institute for Environmental Research Report to the Murray-Darling Basin Commission, Arthur Rylah Institute for Environment Research Report, Department of Sustainability and Environment. MDBA Publ

Editorial responsibility: Steven Cooke,

Ottawa, Ontario, Canada
No. 14/09, Murray-Darling Basin Authority, Canberra

Todd CR, Nicol SJ, Koehn JD (2004) Density-dependence uncertainty in population models for the conservation of trout cod, Maccullochella macquariensis. Ecol Model 171:359-380

Tonkin Z, King AJ, Mahoney J (2008) Effects of flooding on recruitment and dispersal of the southern pygmy perch (Nannoperca australis) at a Murray River floodplain wetland. Ecol Manag Restor 9:196-201

Trueman W (2011) True tales of the trout cod: river histories of the Murray-Darling Basin. MDBA Publ No. 215/11, Murray-Darling Basin Authority, Canberra

Waters JM, Shirley M, Closs GP (2002) Hydroelectric development and translocation of Galaxias brevipinnis: A cloud at the end of the tunnel? Can J Fish Aquat Sci 59: 49-56

Whittington R, Becker J, Tweedie A, Gilligan D, Asmus M (2010) Susceptibility of previously untested basin fish species to Epizootic Haematopoietic Necrosis Virus (EHNV) and its epidemiology in the wild. Final report to Murray-Darling Basin Authority, University of Sydney

> Woodcock SH, Gillanders BM, Munro AR, McGovern F, Crook DA, Sanger AC (2011) Using enriched stable isotopes of barium and magnesium to batch mark otoliths of larval golden perch (Macquaria ambigua, Richardson). Ecol Freshw Fish 20:157-165

Submitted: May 30, 2011; Accepted: October 27, 2011 Proofs received from author(s): February 10, 2012 